\title{
Sulfobacillus disulfidooxidans sp. nov., a New Acidophilic, Disulfide-Oxidizing, Gram-Positive, Spore-Forming Bacterium
}

\author{
S. DUFRESNE, ${ }^{1}$ J. BOUSQUET, ${ }^{2}$ M. BOISSINOT, ${ }^{1}$ AND R. GUAY ${ }^{1 *}$ \\ Département de Microbiologie ${ }^{1}$ and Centre de Recherche en Biologie Forestière, ${ }^{2}$ \\ Université Laval, Ste-Foy, Québec, Canada G1K 7P4
}

\begin{abstract}
An acidophilic, disulfide-oxidizing, mesophilic, aerobic bacterium was isolated from wastewater sludge. The new organism is a gram-positive sporulated rod. It can use elemental sulfur and pyrite as sole energy sources and grows on organic substrates such as glutamate and glucose. It also grows on the following organic sulfur substrates: oxidized and reduced glutathione, cysteine, cystine, and dithio(bis)benzothiazole and clearly shows a preference for disulfide bond-containing substrates. The optimal $\mathrm{pH}$ of growth is between 1.5 and 2.5 , depending on the substrate used, and the growth temperature range varies from 4 to $40^{\circ} \mathrm{C}$, with an optimal value at $35^{\circ} \mathrm{C}$. The $\mathrm{G}+\mathrm{C}$ chromosomal DNA content was measured at $53 \pm 1 \mathrm{~mol} \%$. Phylogenetic analysis of 16S genes coding for rRNA sequences places the new isolate in the genus Sulfobacillus. In addition, unique phenotypic and physiologic characteristics and DNA homology values assign the isolate to a new species in the genus. Therefore, this new isolate has been named Sulfobacillus disulfidooxidans and has been assigned ATCC number 51911.
\end{abstract}

Many facultatively heterotrophic bacteria are known for their ability to grow under highly acidic conditions. Some of these within the genera Sulfolobus (5) and Acidianus (31) are extremely thermophilic archaebacteria. They obtain their energy by the oxidation or reduction of elemental sulfur or from organic substrates. Others are mesophilic gram-negative bacteria belonging to the genus Acidiphilium $(2,18)$ and are able to use organic substrates at $\mathrm{pH} 3.0$ or belong to the genus Thiobacillus, such as Thiobacillus acidophilus (17), which is also known for its ability to grow with elemental sulfur or glucose at $\mathrm{pH} 2.5$.

However, the only acidophilic, facultatively autotrophic, gram-positive, spore-forming bacillus so far characterized is Sulfobacillus thermosulfidooxidans (16), together with two subspecies ("thermotolerans" and "asporogenes") that do not produce spores (19). Golovacheva and Karavaiko (16) first described the genus Sulfobacillus in 1978 as gram-positive, sporeforming bacteria growing on elemental sulfur, ferrous iron, and other metal sulfides. The rod-shaped cells were described as fairly pleomorphic. The spores were spherical or slightly oval, terminal, subterminal, or paracentral. $S$. thermosulfidooxidans is a typical acidophilic, thermotolerant, and facultatively autotrophic bacterium. Since then, four isolates which are gramvariable, thermotolerant acidophiles have been recovered from mines: ALV (27), BC (27), C-MT1 (15), and TH3 (4), and have been described as belonging presumably to this genus. Some other gram-positive bacteria from the genus Alicyclobacillus (7-9) can also grow under acidic conditions, but they are heterotrophic bacteria.

This work reports on the isolation and characterization of a new facultatively autotrophic, mesophilic, acidophilic, grampositive, spore-forming bacterium (SD-11) that could belong to the genus Sulfobacillus.

\section{MATERIALS AND METHODS}

Bacterial strains and culture conditions. The acidophilic strain SD-11 was isolated from a mixed culture obtained after enrichment of wastewater sludge of Blake Lake City, Québec, Canada, with elemental sulfur and further plating on thiosulfate agar adjusted to $\mathrm{pH} 4.0$ (11). Escherichia coli K-12 ATCC 10798 was

\footnotetext{
* Corresponding author.
}

used for reference purposes with regard to molecular DNA analysis. Modified 9K medium (9K-EL) (32) was used as the basalt growth medium for strain SD-11, and the ferrous sulfate used as the energy source in $9 \mathrm{~K}$ medium was replaced by organic and inorganic substrates at a final concentration of $2.5 \mathrm{~g} / \mathrm{liter}$. Yeast extract was added $(0.1 \mathrm{~g} /$ liter $)$ as a growth factor. The $\mathrm{pH}$ of the liquid medium was adjusted to 2.25 with $2 \mathrm{~N} \mathrm{H}_{2} \mathrm{SO}_{4}$. Four different substrates were tested: sodium glutamate, oxidized and reduced glutathione (Aldrich Chemical Co.) sterilized by filtration, and tyndallized elemental sulfur. They were added to autoclaved $250-\mathrm{ml}$ flasks containing $100 \mathrm{ml}$ of basalt salt medium $9 \mathrm{~K}-\mathrm{EL}$. The isolate was cultured at $30^{\circ} \mathrm{C}$ for 7 days in a gyratory incubator shaker at $200 \mathrm{rpm}$. $E$. coli was cultured in Trypticase soy broth (BBL) overnight at $37^{\circ} \mathrm{C}$. All chemical reagents used in this study were analytical grade.

Phenotypic characterization. The $\mathrm{pH}$ and temperature range for growth were determined for three different substrates (sulfur, sodium glutamate, and oxidized glutathione). The growth was monitored by measurement of the protein content determined according to the method of Lowry et al. (23) as modified by Fieg (12) for culturing on sulfur. Growth was also estimated in 9K-EL with oxidized glutathione as the substrate in an anaerobic chamber at $30^{\circ} \mathrm{C}$ after 10 and 20 days of incubation. No electron acceptor besides oxidied glutathione, sulfates, or traces of nitrate was added during anaerobic incubation.

The commercially available API $50 \mathrm{CH}$ system (BioMerieux), described by Deinhard et al. (8) for the biochemical profile characterization of Alicyclobacillus acidoterrestris, was used with minor modifications to evaluate carbohydrate utilization by strain SD-11. The 9K-EL at $\mathrm{pH} 2.25$, to which bromophenol blue was added as a $\mathrm{pH}$ indicator, replaced the Bacillus acidocaldarius medium. The inoculated medium was incubated at $30^{\circ} \mathrm{C}$, and growth was monitored by examining turbidity and/or acidification every 3 days for 15 days.

Cellular morphology was recorded with a Nikon Optiphot phase-contrast microscope. Polyphosphate granules were stained with Loeffler's methylene blue solution (28). Fine morphological features were revealed by transmission and scanning electron microscopy. A washed cell suspension of strain SD-11 was fixed in a $5.0 \%$ glutaraldehyde solution in $0.2 \mathrm{M}$ phosphate buffer (pH 7.2), followed by post-fixation in a $3 \% \mathrm{OsO}_{4}$ solution. Dehydration was carried out in a graded ethanol series. Cells were embebded in LR white resin, and cell sections were obtained with a Reichert OM V2 ultramicrotome. They were stained with lead hydroxide $(5 \%)$ and uranyl acetate $(5 \%)$ solutions and examined on a Philips EM 300 transmission electron microscope at $80 \mathrm{kV}$. Negative staining was carried out as follows: $5 \mu \mathrm{l}$ of a culture suspension was allowed to air dry on a formvar-coated copper grid (size $200 \mathrm{HH}$ ), $5 \mu \mathrm{l}$ of sodium phosphotungstate solution (2\% [pH 7.2]) was added, and the grid was dried on filter paper. The specimens were examined by transmission electron microscopy at $60 \mathrm{kV}$. Scanning electron microscopy was performed on a deposit obtained from a sample of culture $(100 \mu \mathrm{l})$ passed through a $13-\mathrm{mm}$ polycarbonate $(0.1 \mu \mathrm{m}$ pore size $)$ Nucleopore filter. The filters were treated according to the procedure of Blais et al. (3), and the fixed specimen was examined with a JEOL JMS-T330A electron scanning microscope.

DNA base composition. Genomic DNA was extracted and purified according to the method of Marmur (25), and $\mathrm{G}+\mathrm{C}$ content was determined from the thermal melting profile (midpoint temperature) (26).

$16 S$ rDNA phylogenetic analyses. $E$. coli and SD-11 cells were harvested and washed and nucleic acids were extracted by a previously published procedure (1). 
TABLE 1. Positions of the primers used for PCR amplification of 16S rDNA

\begin{tabular}{lcll}
\hline \multicolumn{1}{c}{ Primer } & Position $^{a}$ & \multicolumn{1}{c}{ Sequence } & Reference $^{\prime}$ \\
\hline SSU 27 & $8-27$ & $5^{\prime}$-AGAGTTTGATCMTGGCTCAG-3' & 10 \\
SSU 785' & $785-805$ & $5^{\prime}$-GGACTACCAGGGTATCTAATC-3' & This study $^{\prime}$ \\
SSU 536 & $515-536$ & $5^{\prime}$-GTGCCAGCMGCCGCGGTAATAC-3' & This study $^{\prime}$ \\
SSU 1175' & $1175-1195$ & $5^{\prime}$-GACGTCATCCCCTCCTTCCTC-3' & This study $^{\prime}$ \\
SSU 926 & $908-926$ & $5^{\prime}$-AAACTYAAAKGAATTGACGG-3' & This study $^{\prime}$ \\
SSU 1492' & $1492-1508$ & $5^{\prime}$-TACGGYTACCTTGTTACGACTT-3' & 10 \\
\hline
\end{tabular}

${ }^{a}$ Relative to $E$. coli $16 \mathrm{~S}$ rDNA sequence.

Genes coding for 16S rRNA (rDNA) fragments corresponding to the positions 8 to 1510 of $E$. coli $16 \mathrm{~S}$ rDNA (6) were amplified by PCR. The later sequence was amplified in overlapping fragments with the three sets of primers described in Table 1. DNA amplification was conducted in a Perkin-Elmer Cetus GenAmp PCR System 9600 under the following conditions: a preheating cycle at $98^{\circ} \mathrm{C}$ for $1 \mathrm{~min}$, followed by 30 amplification cycles with profiles for DNA denaturation, primer annealing, and primer extension steps of 98,62 , and $72^{\circ} \mathrm{C}$ for 10,5 , and $15 \mathrm{~s}$, respectively; for the SSU $27-\mathrm{SSU} 785^{\prime}$ primer pair and 98,55 , and $72^{\circ} \mathrm{C}$ for 10,5 , and $15 \mathrm{~s}$ for the other two primer pairs. After $30 \mathrm{cycles}$, the reactions were stopped, and PCR products were purified by QIA quick-spin column chromatography (QIAGEN, Chatworth, Calif.). Both strands were sequenced with an ABI 372 automated sequencer with Taq dyedeoxy cycle sequencing (PE-ABI, Foster City, Calif.).

The 16S rDNA sequence of strain SD-11 was first aligned with one of its most similar sequences, the $16 \mathrm{~S}$ rDNA of $S$. thermosulfidooxidans by the ALIGN MENT procedure of the Ribosomal Database Project (24). The SD-11 sequence was aligned manually on the already available alignment of $16 \mathrm{~S}$ rDNA sequences from 15 species, including $S$. thermosulfidooxidans, obtained from the Ribosomal Database Project (SUBALIGN procedure). Ambiguous regions (positions 1 to 225,452 to 481,998 to 1044 , and 1510 to 1546 ) were removed, and the resulting alignment of 1,208 nucleotides was submitted to phylogenetic analyses. Standard parsimony analysis was conducted with the heuristic algorithm of PAUP, version 3.1.1 (34), in which minimal gaps were considered as missing values. Sequences were submitted in 100 different random orders. Pairwise sequence identities were also estimated and transformed in rates of substitution by the two-parameter method of Kimura (20), which takes into account transitions and transversions. The resulting matrix of substitution rates was submitted to neighbor-joining analysis (30) with MEGA, version $1.0(21)$. Confidence levels for the tree topologies obtained were estimated by a bootstrap procedure (14) with 100 replicates for both parsimony (PAUP) and neighbor-joining analysis (MEGA). In all cases, the gram-negative E. coli, T. acidophilus, and T. thiooxidans were used as outgroups for rooting the gram-positive tree.

Nucleotide sequence accession number. The 16S rDNA sequence of strain SD-11 obtained in this study has been deposited in the GenBank nucleotide sequence database under accession number U34974. The accession numbers used as reference sequences are as follows: Alicyclobacillus acidocaldarius, X60742; Alicyclobacillus acidoterrestris, X60743; Alicyclobacillus cycloheptanicus, X51928; Bacillus subtilis, K00637, M10606, and X00007; Clostridium innocuum, M23732; E. coli, J01695; Mycobacterium bovis, M20940; Sporolactobacillus inulinis, M58838; Streptomyces lividans, Y00484; strain ALV, M79375, M79376, and M80290; strain BC, M79380 to M79382; strain TH3, M79433 and M79434; Thiobacillus thiooxidans, X75269; and Thiobacillus acidophilus, M79399 and M79400.

\section{RESULTS}

Isolation and growth. The new species was isolated from a mixed culture obtained after enrichment from a Blake Lake City sludge sample with elemental sulfur and further plating on thiosulfate agar adjusted to $\mathrm{pH} 4.0$ (11). A pure culture of SD-11 was obtained through micromanipulation of tiny colonies of the isolated mixed culture and further grown in enrichment broth $9 \mathrm{~K}-\mathrm{EL}$ supplemented with oxidized glutathione at $\mathrm{pH} 2.25$. Since strain SD-11 showed active sporulation after prolonged growth on the latter liquid medium, the mixed population was subjected to heat treatment. Mixed suspensions of cells were therefore boiled for $30 \mathrm{~min}$, after which spore preparations were left to cool at room temperature. Successful germination could only be reached after storage at 2 to $4^{\circ} \mathrm{C}$ for 18 to $24 \mathrm{~h}$. Culture purity was verified by plating of a $10-\mu \mathrm{l}$ inoculum on a thiosulfate agar surface and on other solidified media. It should be noted that under the indicated conditions, strain SD-11 could not be grown in pure culture on solidified media. The growth on solid medium was obtained only when a thiosulfate-oxidizing, acidophilic bacterium was cocultivated with strain SD-11. Absence of growth when a pure culture inoculum was used indicated the absence of contaminating bacteria. Pure culture floculated when grown in liquid media.

Morphology and ultrastructure. Isolate SD-11 is a pleomorphic, rod-shaped, spore-forming, nonmotile bacterium; it has been impossible to obtain a satisfactory Gram staining of a fixed or unfixed bacterial cell suspension, even if the preparation originated from a young and active culture. Under electron microscopy, it exhibits the typical smooth texture of the membrane of gram-positive bacteria (Fig. 1A and B). The cells occur singly and often in pairs when grown on sulfur, or they tend to form filaments when grown on oxidized glutathione (Fig. 1A and B). Cellular divisions seem to be atypical, as shown on Fig. 1A; asymmetric divisions and mini-cell-like structures were regularly observed under various growth conditions. Polyphosphate granules and spores were also observed at opposite ends of the cells; polyphosphate granules seem to disappear slowly when the sporulation process is initiated (Fig. $1 \mathrm{~B}$ and $\mathrm{C}$ ).

Physiological and biochemical characteristics. Isolate SD-11 appears to be an aerobic microorganism; even if strain SD-11 grows poorly under anaerobic conditions, only one fifth of the cellular yield obtained in aerobiosis was achieved in the absence of oxygen with oxidized glutathione as the energy source. Strain SD-11 is a mixotroph and uses a wide variety of organic and inorganic substrates as described in Table 2. Growth yields were measured with inorganic substrates, such as elemental sulfur and pyrite, and with organic substrates such as glucose, glutamic acid, and oxidized glutathione. Among organic sulfur compounds, those containing disulfide bonds were preferred over the thiol groups $(-\mathrm{SH})$. On the basis of total protein content, generation time varied from 6 to $49 \mathrm{~h}$. Culture of the bacteria on yeast extract as sole substrate was not possible. However, when yeast extract was added to the culture media at a final concentration of $0.1 \mathrm{~g} /$ liter, it enhanced growth by providing essential growth factors. Table 3 presents results on growth and utilization of various carbohydrates by isolate SD-11 in the API $50 \mathrm{CH}$ galleries: only a few substrates, including amygdalin, glucose, maltose, and melezitose, could support fast growth. However, glucose was the sole substrate on which the organism was able to achieve a noticable growth. No decrease in $\mathrm{pH}$ was observed for any of the 49 other substrates.

Temperature and $\mathrm{pH}$ conditions allowing growth were tested in 9K-EL supplemented with elemental sulfur, sodium glutamate, or oxidized glutathione. Growth was possible from 4 to $40^{\circ} \mathrm{C}$, with an optimum at $35^{\circ} \mathrm{C}$; no growth was detected above $40^{\circ} \mathrm{C}$. Isolate SD- 11 grew between $\mathrm{pH} 0.5$ and 6.0 , and the optimum value varied between 1.5 and 2.5 , depending on 

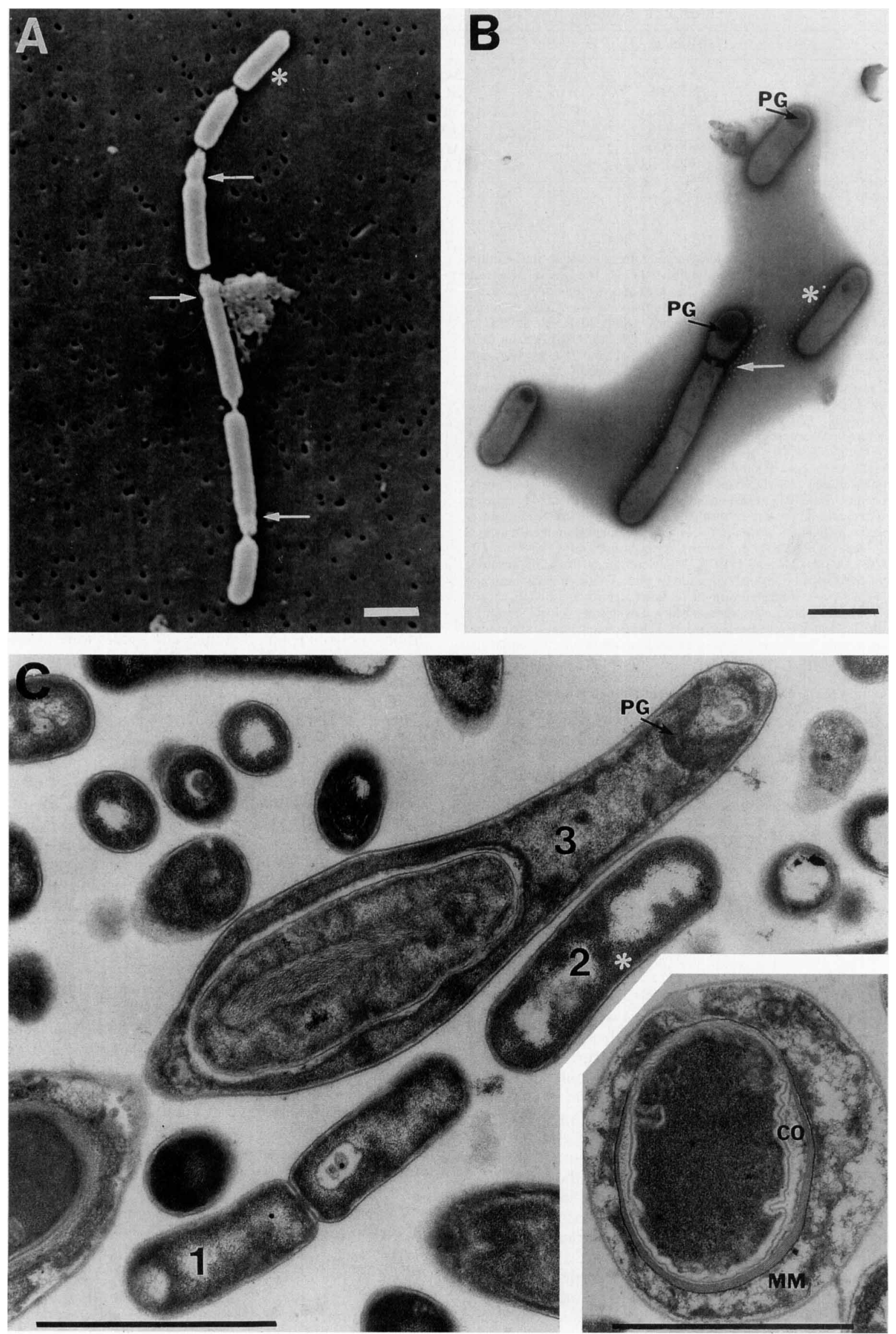
FIG. 1. Electron micrographs of SD-11 isolates. (A) Scanning electron micrograph showing a short chain of abnormally dividing (arrows) and normal-length ( ${ }^{*}$ ) cells. (B) Transmission electron micrograph of negatively stained preparation showing the polyphosphate granules (PG) both in abnormally dividing (white arrow) and normal-length (*) SD-11 cells. (C) Transmission electron micrographs of ultrathin longitudinal and tranverse sections of SD-11 cells at different stages of growth: 1 , dividing vegetative cells; 2 , mature vegetative cell (normal length $\left[{ }^{*}\right]$ ); 3 , sporulating cell with polyphosphate granule and highly deforming prespore at opposite end. (Insert) Transverse section of sporulating SD-11 cell showing prespore multilamellar membrane (MM) and cortex (CO). Bar, $1 \mu \mathrm{m}$.

the substrate used. The initial $\mathrm{pH}$ of the culture media did not change during growth.

DNA analyses and phylogenetic relationships. The genomic DNA G + C content of strain SD-11 was $53 \pm 1 \mathrm{~mol} \%$, and the $\mathrm{G}+\mathrm{C}$ nucleotide ratio of the $16 \mathrm{~S}$ rDNA was $59.3 \mathrm{~mol} \%$. From 16S rDNA nucleotide sequence data, isolate SD-11 shares 95.5\% homology with $A$. cycloheptanicus and $95.2 \%$ homology with $S$. thermosulfidooxidans (Table 4). The transition/transversion ratios were 1.3 for strain SD-11 versus $S$. thermosulfidooxidans and 1.1 for strain SD-11 versus $A$. cycloheptanicus.

The tree topologies estimated from both standard parsimony and neighbor-joining analyses of two-parameter substitution rates showed close relatedness between the genera Sulfobacillus and Alicyclobacillus. This group was supported by a high bootstrap value, which indicates the degree of statistical confidence (Fig. 2). In both analyses, the genus Alicyclobacillus did not appear monophyletic, because its taxa were intermingled with the genus Sulfobacillus. This arrangement was supported by high bootstrap values. The only topological difference between parsimony and neighbor-joining trees was the placement of the Bacillus-Sporolactobacillus-Clostridium group, which shows low percentage $\mathrm{G}+\mathrm{C}$ content together with the Sulfobacillus-Alicyclobacillus group. Parsimony placed both groups together, and this was supported by a bootstrap value of $85 \%$ (Fig. 2A); this topology is in accordance with previous studies (22). Neighbor-joining analysis placed the Sulfobacillus-Alicyclobacillus group next to the intermediate-percentage$\mathrm{G}+\mathrm{C}$-content group formed by the strains BC and ALV (Fig. 2B). However, this alternative arrangement was supported by a lower bootstrap value $(58 \%)$ ). To further investigate this lack of congruence, the phylogeny was estimated with Gary Olsen's fastDNAm1 program (Ribosomal Database Project) (24), which is based on the maximum-likelihood approach (13). The 16S rDNA sequence of the strain C-MT1 (GenBank entry $\mathrm{X} 75270$ ), isolated by Goebel and Stackebrandt (15) and presumably identified as a member of the genus Sulfobacillus on preliminary physiological analysis, was also included. The max-

TABLE 2. Generation time of strain SD-11 grown on different substrates in 9K-EL liquid medium at $\mathrm{pH} 2.25$ at $30^{\circ} \mathrm{C}$

\begin{tabular}{llr}
\hline \multicolumn{1}{c}{ Substrate } & \multicolumn{1}{c}{$\begin{array}{c}\text { Mean generation } \\
\text { time }(\mathrm{h})\end{array}$} & $\begin{array}{c}\text { Growth } \\
(\%)^{a}\end{array}$ \\
\hline $\begin{array}{l}\text { Inorganic } \\
\text { Elemental sulfur }\end{array}$ & $13\left(6\right.$ h at $\left.35^{\circ} \mathrm{C}\right)$ & 66 \\
Pyrite & 16 & 56 \\
$\quad$ Ferrous sulfate & 25 & 30 \\
Organic & 12 & 68 \\
Glutamate & 26 & 12 \\
Glycine & 16 & 88 \\
Glucose & $12\left(7\right.$ h at $\left.35^{\circ} \mathrm{C}\right)$ & 100 \\
Oxidized glutathione $(-\mathrm{S}-\mathrm{S})$ & 72 \\
Reduced glutathione $(-\mathrm{SH})$ & 28 & 61 \\
Thiourea (-S-S- $-\mathrm{S})$ & 24 & 54 \\
Cystamine $(-\mathrm{S}-\mathrm{S}-)$ & 28 & 53 \\
Cystine $(-\mathrm{S}-\mathrm{S}-)$ & 42 & 17 \\
Cysteine $(-\mathrm{SH})$ & 49 & \\
\hline
\end{tabular}

${ }^{a}$ Recorded as percentage of growth relative to oxidized glutathione at $\mathrm{pH} 2.25$ and $30^{\circ} \mathrm{C}$. imum-likelihood tree obtained was very similar to the parsimony tree, and the strain C-MT1 clustered with the strains BC and ALV. The newly isolated strain SD-11 was found with the low-percentage- $\mathrm{G}+\mathrm{C}$ strains of the genera, which were regrouped by the analysis.

\section{DISCUSSION}

This study has provided phenotypic and genotypic information about the newly isolated strain SD-11. This strain, isolated from a wastewater sludge treatment plant, is a gram-positive, mesophilic, acidophilic, and aerobic bacterium. However, the organism may grow as a facultative anaerobe, since oxidized glutathione seems to be used as a substrate under anaerobiosis. Under the anaerobic growth conditions used during the experiments, we favor the anaerobic respiration hypothesis, although no significant data support it except for the very low cellular yield during incubation. We estimated that only $20 \%$ of the anaerobiosis cellular yield was reached after 20 days of culturing under anaerobiosis. Its morphological features and mixotrophic metabolism suggest that strain SD-11 most likely belongs to the genus Sulfobacillus. The morphological characteristics of isolate SD-11 are similar to those described for $S$. thermosulfidooxidans (Table 5). Both are gram-positive, nonmotile, rod-shaped bacteria which form chains or straight or interwoven filaments ( $S$. thermosulfidooxidans subsp. "asporogenes"). SD-11 exhibits subterminal, deforming spores. The analysis of the fatty acid composition in bacteria belonging to the genera Alicyclobacillus and Sulfobacillus revealed the pres-

TABLE 3. Relative growth of strain SD-11 on the different substrates of the API $50 \mathrm{CH}$ system

\begin{tabular}{|c|c|c|c|}
\hline \multicolumn{4}{|c|}{ Substrate on which relative growth is ${ }^{a}$ : } \\
\hline- & + & ++ & +++ \\
\hline Control & Adonitol & Starch & Amygdalin \\
\hline Arbutin & D- and L-Arabinose & L-Arabitol & Glucose \\
\hline Dulcitol & D-Arabitol & $\mathrm{N}$-Acetyl-glucos- & Maltose \\
\hline Erythritol & Cellobiose & amine & Melezitose \\
\hline Fructose & Esculin & Glycogen & \\
\hline L-Fucose & D-Fucose & Inulin & \\
\hline Galactose & Gentiobiose & Sucrose & \\
\hline Inositol & Glycerol & & \\
\hline Lactose & Gluconate & & \\
\hline D-Lyxose & 2-Keto-gluconate & & \\
\hline Mannitol & 5-Keto-gluconate & & \\
\hline Mannose & $\alpha$-Methyl-D-glucoside & & \\
\hline Rhamnose & Melibiose & & \\
\hline Salicin & $\alpha$-Methyl-D-mannoside & & \\
\hline Trehalose & Ribose & & \\
\hline D-Turanose & Raffinose & & \\
\hline Xylitol & Sorbitol & & \\
\hline$\beta$-Methyl-D- & Sorbose & & \\
\hline xyloside & D-Tagatose & & \\
\hline & $D$ and L-Xylose & & \\
\hline
\end{tabular}

${ }^{a}$ Growth was evaluated visually under phase-contrast microscopy in the absence of turbidity. - , presence of sporulated cells only or no growth; + , few isolated cells; ++ , short chains of long cells; +++ , chains of short cells (fast dividing cells). 
ence of $\omega$-cyclohexane acids (or $\omega$-cycloheptane in $A$. cycloheptanicus) $(8,9,36)$, which are rarely seen in other bacteria. The fatty acid composition for strain SD-11 closely resembles that of $S$. thermosulfidooxidans. The presence of $\omega$-cyclohexane $C_{17}$ and $\mathrm{C}_{19}$ was revealed in this new organism (29). The $\mathrm{G}+\mathrm{C}$ contents were found to be $53 \pm 1 \mathrm{~mol} \%$ and $54 \pm 1 \mathrm{~mol} \%$, respectively, for SD-11 and $S$. thermosulfidooxidans, and were identical at $59 \pm 1 \mathrm{~mol} \%$ for their $16 \mathrm{~S}$ rDNA sequences (35).

However many physiological differences were noted between isolate SD-11 and Sulfobacillus sp. and Alicyclobacillus sp. The species of the genera Sulfobacillus and Alicyclobacillus grow better at temperatures above $45^{\circ} \mathrm{C}$, whereas isolate SD- 11 is more typical of a mesophilic species $\left(35^{\circ} \mathrm{C}\right)$. The new isolate does not grow on solid media, even with the use of phytagel, agarose, silicate gel, or starch as solidifying agents. It grows autotrophically on elemental sulfur and on pyrite with the production of sulfur oxyanions, including sulfate, in contrast with $S$. thermosulfidooxidans, which oxidizes sulfur to sulfuric acid. It can also grow heterotrophically on carbohydrates like glucose, without any production of acidic end products, and also on amino acids like glutamate. The new organism shows a net preference for organic sulfur substrates (Table 6). The API $50 \mathrm{CH}$ system was also used to compare the utilization of carbohydrates by isolate SD-11 and by strains from the genus Alicyclobacillus, the major difference again being the lack of acidification observed after growth of isolate SD-11 $(8,9)$. As a consequence of the differences in phenotypic and physiological characteristics, the isolate SD-11 may be classified as a new species of the genus Sulfobacillus.

The analysis of the $16 \mathrm{~S}$ rDNA sequences showed that strain SD-11 is phylogenetically closely related to the genera Sulfobacillus and Alicyclobacillus. Even if the genera Sulfobacillus and Alicyclobacillus possess a number of distinctive phenotypic features that could justify their separation into two genera (Table 7), phylogenetic analyses confirm their close proximity (35). Since $A$. cycloheptanicus is found to be more related to $\mathrm{Sul}$ fobacillus strains than to other Alicyclobacillus strains, and because both groups share growth factor requirements (Table 7), a revision of the taxonomic nomenclature of the group at the genus level may be necessary, but this will require the description of additional species.

Signature sequences (513-A, 1207-C, 168-G, 906-G, 955-G, and 1167-A according to the $E$. coli numbering convention) support the assignment of strain SD-11 as a gram-positive organism of the low-percentage- $\mathrm{G}+\mathrm{C}$ subdivision (22). The 14 conserved nucleotide positions reported by Tourova et al. (35), which link the genera Alicyclobacillus and Sulfobacillus and differentiate them from the other low-percentage- $\mathrm{G}+\mathrm{C}$ grampositive groups were also found in isolate SD-11 (154-G, 452-G, 480-A, 672-G, 734-C, 748-G, 862-G, 867-C, 1122-G, 1123-T, 1150-A, 1151-C, 1297-G, and 1298-T). However, the clade formed by strains ALV, BC, and C-MT1 was shown by parsimony and maximum-likelihood methods to be quite remote from the genera Sulfobacillus and Alicyclobacillus (22, $35)$, even if the isolate $\mathrm{BC}$ has been described as a gramnegative rod-shaped bacterium $(15,27)$.

For every type of phylogenetic analysis (neighbor joining, parsimony, and maximum likelihood), the closest strain to the isolate SD-11 was $S$. thermosulfidooxidans, and this is supported by the high bootstrap values (Fig. 2). Two signature sequences, 5'-ATGCTACGGCATCGC-3' and 5'-AACCCCT GAAAACCGC- $3^{\prime}$ at positions 200 to 222 and 1279 to 1296 , were found only in both $S$. thermosulfidooxidans and strain SD-11. This further reinforces the very high phylogenetic affinity observed between the Golovacheva's Sulfobacillus isolate 
A
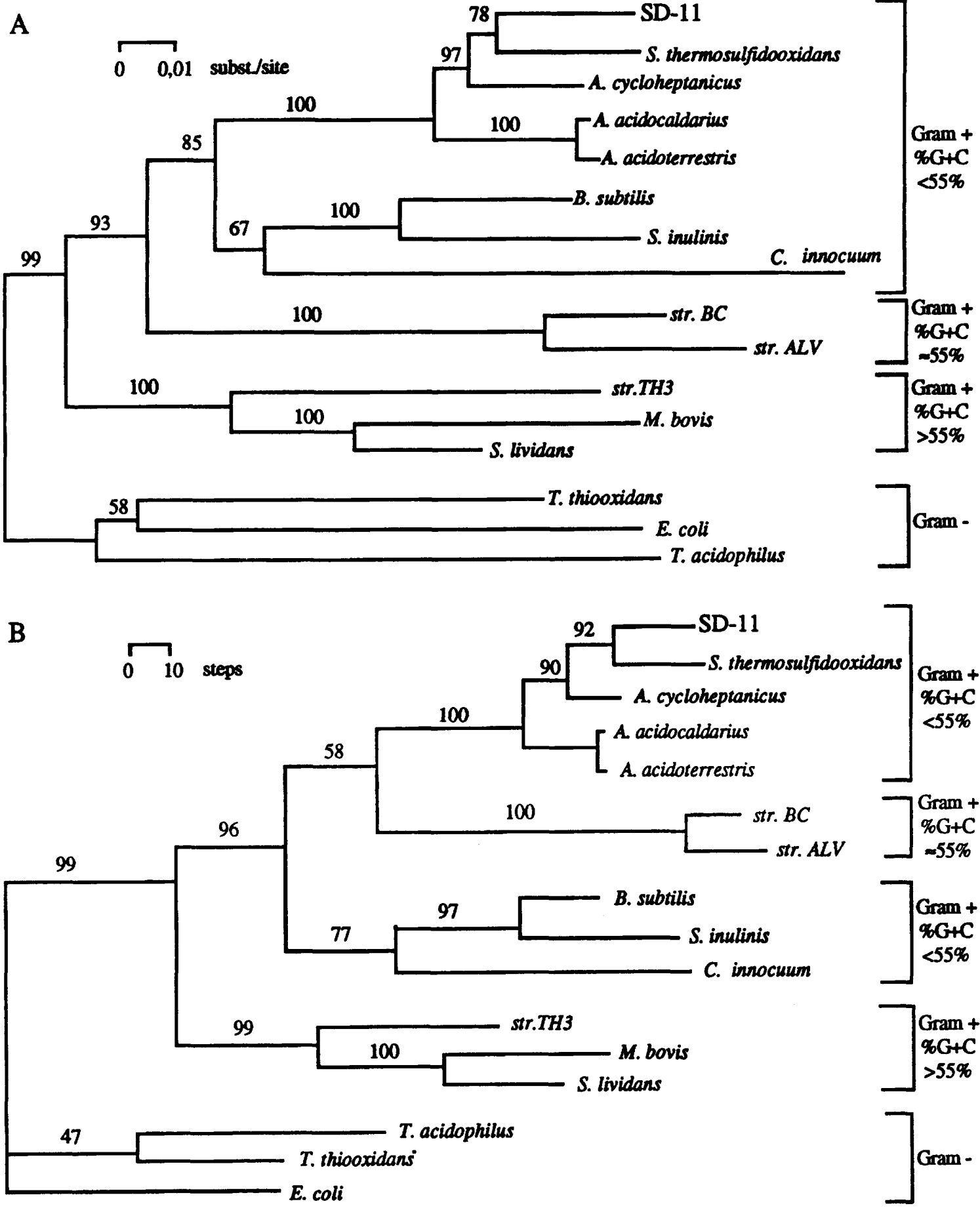

FIG. 2. Phylogenetic relationships among gram-positive bacteria and position of strain SD-11 based on analysis of $16 \mathrm{~S}$ rDNA gene sequences. Gram-negative strains were used as outgroup to root the gram-positive tree. (A) Tree obtained from neighbor-joining analysis of two-parameter substitution (subst.) rates. (B) Tree obtained from standard parsimony analysis. Numbers on branches indicate bootstrap estimates from 100 replicates. For full names of strains, refer to Table 4 . str., strain.

and the bacterium SD-11 isolated from a completely different environment.

Given that the highest $16 \mathrm{~S}$ rDNA sequence homology of strain SD-11 compared with the other bacteria is less than $97.0 \%$ (Table 4), total DNA will not reassociate to more than $60 \%$ with any other piece of DNA from different bacterial strains, no matter which hybridization method is used (33).
Indeed, the highest $16 \mathrm{~S}$ rDNA sequence homology values observed with $A$. cycloheptanicus and $S$. thermosulfidooxidans were less than $96 \%$. Therefore, the isolate SD-11 should be considered formally as a distinct species both from the $16 \mathrm{~S}$ rDNA composition and homology perspective, even if formal DNA-DNA reassociation studies were not conducted.

On the basis of all phenotypic, genotypic, and phylogenetic 


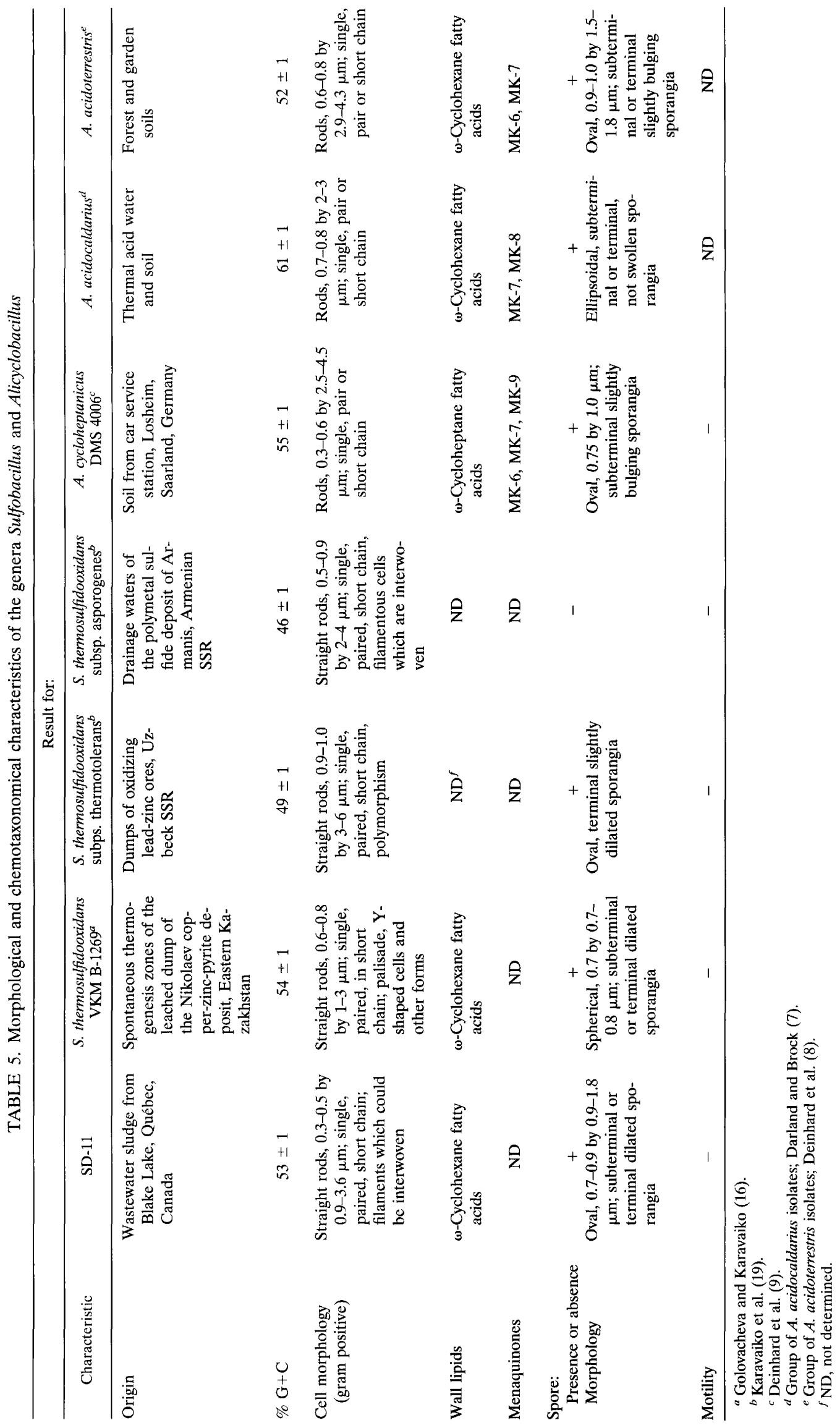


TABLE 6. Physiological characteristics of the genera Sulfobacillus and Alicyclobacillus

\begin{tabular}{|c|c|c|c|c|c|c|c|}
\hline \multicolumn{8}{|c|}{ Result for: } \\
\hline Characteristic & SD-11 & $\begin{array}{c}\text { S. thermosulfidooxidans } \\
\text { VKM B-1269 }\end{array}$ & $\begin{array}{l}\text { S. thermosulfidooxidans } \\
\text { subsp. thermotolerans }\end{array}$ & $\begin{array}{l}\text { S. thermosulfidooxidans } \\
\text { subsp. asporogenes }\end{array}$ & $\begin{array}{l}\text { A. cycloheptanicus } \\
\text { DMS } 4006\end{array}$ & $\begin{array}{l}\text { A. acido- } \\
\text { caldarius }\end{array}$ & $\begin{array}{l}\text { A. acido- } \\
\text { terrestris }\end{array}$ \\
\hline Anaerobic growth & + & - & - & - & + & - & \\
\hline \multicolumn{8}{|l|}{$\mathrm{pH}$} \\
\hline Optimum & $1.5-2.5$ & $1.9-2.4$ & $2.5-2.7$ & $1.6-2.5$ & $3.5-5.5$ & & \\
\hline Growth range & $0.5-6.0$ & $1.5-5.5$ & $1.2-4.2$ & $1.5-4.5$ & $3.0-5.5$ & $2.0-6.0$ & $2.2-5.8$ \\
\hline \multicolumn{8}{|l|}{ Temp } \\
\hline Optimum $\left({ }^{\circ} \mathrm{C}\right)$ & 35 & 50 & $37-42$ & 50 & 48 & & $42-53$ \\
\hline Growth range $\left({ }^{\circ} \mathrm{C}\right)$ & $4-40^{2}$ & $20-60$ & $20-50$ & $20-60$ & $40-53$ & $45-70$ & $35-55$ \\
\hline Growth factor & Yeast extract & Yeast extract & Yeast extract & Yeast extract & $\begin{array}{c}\text { Ile Met or } B_{12} \\
\text { pantothenate }\end{array}$ & - & - \\
\hline \multicolumn{8}{|l|}{ Growth in ${ }^{b}$ : } \\
\hline$S^{0}$ & + & + & + & + & $\mathrm{ND}^{c}$ & ND & ND \\
\hline $\mathrm{Fe}^{2+}$ & $(+)$ & + & + & + & ND & ND & ND \\
\hline $\mathrm{S}_{2} \mathrm{O}_{3}^{-}$ & - & + & ND & ND & ND & ND & ND \\
\hline $\mathrm{Fe}_{2} \mathrm{~S}$ & + & + & + & + & ND & ND & ND \\
\hline Yeast extract & - & + & + & + & + & + & + \\
\hline Acetate & - & + & ND & ND & - & ND & ND \\
\hline Casamino Acids & ND & + & ND & + & + & ND & ND \\
\hline Cystamine & + & ND & ND & ND & ND & ND & ND \\
\hline Cysteine & + & + & ND & + & ND & ND & ND \\
\hline Cystine & + & ND & ND & ND & ND & ND & ND \\
\hline $\begin{array}{l}\text { Dithio(bis)benzo- } \\
\text { thiazole }\end{array}$ & + & ND & ND & ND & ND & ND & ND \\
\hline Galactose & - & - & ND & ND & + & + & + \\
\hline Glucose & + & + & + & + & $+\operatorname{acid}^{d}$ & $+\operatorname{acid}^{d}$ & $+\mathrm{acid}^{d}$ \\
\hline Glutamate & + & + & ND & ND & ND & ND & ND \\
\hline Glutathione & + & ND & ND & + & ND & ND & ND \\
\hline Glycerol & + & ND & ND & ND & + & + & + \\
\hline Meat peptone & - & - & ND & ND & ND & ND & ND \\
\hline \multicolumn{8}{|l|}{ Growth on: } \\
\hline FeTSB & - & + & ND & ND & ND & ND & ND \\
\hline $\begin{array}{l}\text { B. acidocaldarius } \\
\text { medium agar }\end{array}$ & ND & ND & ND & ND & + & + & + \\
\hline
\end{tabular}

${ }^{a}$ Spore germination at $4^{\circ} \mathrm{C}$.

${ }^{b}$ Sulfobacillus sp. strain SD-11 was grown in liquid medium at $\mathrm{pH} 2.25$. Alicyclobacillus sp. was grown in liquid medium at $\mathrm{pH} 4.0$.

${ }^{c} \mathrm{ND}$, not determined.

${ }^{d}$ Acid formation when growth occurs with the substrate.

evidence, the present isolate is formally proposed as a new species within the genus Sulfobacillus.

Description of $S$. disulfidooxidans sp. nov. $S$. disulfidooxidans (di.sul.fi.do.ox'i.dans. L. adj. duplus, double; L. n. sulfur, sulfur; M.L. v. oxido, oxidize; M.L. adj. disulfidooxidans, disulfideoxidizing bacteria). The new species appears as a aerobic, endospore-forming rod shaped bacterium (length, 0.9 to 3.6 $\mu \mathrm{m}$; width, 0.3 to $0.5 \mu \mathrm{m}$ ). The strain is nonmotile; it is a typical gram-positive bacterium, even if Gram staining is variable. $S$. disulfidooxidans produces oval spores, located subterminally in a swollen sporangium. Cells sometime appear pleomorphic and increase in width with aging. Long chains of rods appear only on selected substrates. S. disulfidooxidans does not grow alone on solid medium, but it forms colonies only when an accompanying acidifying bacterium is present and growing.

$S$. disulfidooxidans grows in liquid medium where it literally flocculates. Growth is maximal between $\mathrm{pH} 1.5$ and 2.5, and culture is possible within a wide range of $\mathrm{pH}$, from 0.5 to 6.0 . The Sulfobacillus strain grows best at $35^{\circ} \mathrm{C}$ and within an interval of 4 to $40^{\circ} \mathrm{C}$. $S$. disulfidooxidans utilizes glucose, glutamate, oxidized glutathione, or dithio(bis)benzothiazole during its heterotrophic growth. When the bacterium uses elemental sulfur as its sole energy source, it does not oxidize it to sulfuric acid, but yeast extract is needed as a growth factor. No acid formation has been observed during culture on carbohydrates (API $50 \mathrm{CH}$ ).

The $\mathrm{G}+\mathrm{C}$ content of the extracted DNA is $53 \pm 1 \mathrm{~mol} \%$ as

TABLE 7. Features differentiating the genera Sulfobacillus and Alicyclobacillus

\begin{tabular}{|c|c|c|}
\hline \multirow{2}{*}{ Characteristic } & \multicolumn{2}{|c|}{ Result for genus: } \\
\hline & Sulfobacillus ${ }^{a}$ & Alicyclobacillus ${ }^{b}$ \\
\hline Growth at $25^{\circ} \mathrm{C}$ & + & - \\
\hline Growth at $\mathrm{pH} 2$ & + & - \\
\hline Growth factors required & + & $-{ }^{c}$ \\
\hline Autotrophic growth & + & $\mathrm{DU}^{d}$ \\
\hline Growth on galactose & - & + \\
\hline Acid produced from carbohydrates & - & + \\
\hline
\end{tabular}

${ }^{a}$ This work and that of Golovacheva and Karavaiko (16).

${ }^{b}$ Darland and Brock (7) and Deinhard et al. $(8,9)$.

${ }^{c}$ Except $A$. cycloheptanicus (see Table 6).

${ }^{d}$ DU, data unavailable. 
determined by the thermal denaturation profiles. Its highest $16 \mathrm{~S}$ rDNA sequence identities were 95.5 and $95.2 \%$ with $A$. cycloheptanicus and $S$. thermosulfidooxidans, respectively. As determined by neighbor-joining, parsimony, and maximumlikelihood approaches, the closest phylogenetically to $S$. disulfidooxidans is $S$. thermosulfidooxidans, followed by strains from the genus Alicyclobacillus, both genera forming a highly supported clade of low-percentage-G+C gram-positive strains.

S. disulfidooxidans SD-11 has been deposited at the American Type Culture Collection, Rockville, Md., and has been designated ATCC 51911.

\section{ACKNOWLEDGMENTS}

We thank A. Roy from Centre de Recherche en Biologie Forestière,

F. Garneau and L. Simon for excellent technical assistance, and M. Goldner for comments on the manuscript.

Financial support of the FCAR-CRIQ to S.D. is gratefully acknowledged.

\section{REFERENCES}

1. Ausubel, F. M., R. Brent, R. E. Kingston, D. D. Moore, J. G. Seidman, J, A Smith, and K. Struhl. 1992. Short protocol in molecular biology: a compendium of methods from current protocols in Molecular Biology, p. 2.10 and 2.11. Cold Spring Harbor Laboratory, Cold Spring Harbor, N.Y.

2. Bhattacharyya, S., B. K. Chakrabarty, A. Das, P. N. Kundu, and P. C Banerjee. 1991. Acidiphilium symbioticum sp. nov. an acidophilic heterotrophic bacterium from Thiobacillus ferrooxidans cultures isolated from Indian mines. Can. J. Microbiol, 37:78-85.

3. Blais, J. F., R. D. Tyagi, and J. C. Auclair. 1992. Bioleaching of metals from sewage sludge by sulfur-oxidizing bacteria. J. Environ. Eng. Div. (ASCE) 118:690-707.

4. Brierley, J. A. 1978. Thermophilic iron-oxidizing bacteria found in copper leaching dumps. Appl. Environ. Microbiol. 36:523-525.

5. Brock, T. D., K. M. Brock, R. T. Belly, and R. L. Weiss. 1972. Sulfolobus: a new genus of sulfur-oxidizing bacteria living at low $\mathrm{pH}$ and high temperature. Arch. Microbiol. 84:54-68.

6. Brosius, J., J. L. Palmer, J. P. Kennedy, and H. F. Noller. 1978. Complete nucleotide sequence of a $16 \mathrm{~S}$ ribosomal RNA gene from Escherichia coli. Proc. Natl. Acad. Sci. USA 75:4801-4805.

7. Darland, G., and T. Brock. 1971. Bacillus acidocaldarius sp. nov., an acidophilic thermophilic spore-forming bacterium. J. Gen. Microbiol. 67:9-15.

8. Deinhard, G., P. Blanz, K. Poralla, and E. Altan. 1987. Bacillus acidoterrestris sp. nov., a new thermotolerant acidophile isolated from different soils. Syst. Appl. Microbiol. 10:47-53.

9. Deinhard, G., J. Saar, W. Krischke, and K. Poralla. 1987. Bacillus cyclopheptanicus sp. nov., a new thermoacidophile containing $\omega$-cycloheptane fatty acids. Syst. Appl. Microbiol. 10:68-73.

10. Dorch, M., and E. Stackebrandt. 1992. Some modifications in the procedure of direct sequencing of PCR amplified 16S rDNA. J. Microbiol. Methods 16:271-279.

11. Dufresne, S., J. F. Blais, C. Roy, and R. Guay. 1993. Municipal waste water treatment plant sludges: a source of organic carbon-tolerant, sulfur-oxidizing Thiobacillus and Sulfobacillus strains, p. 267-276. In A. E. Torma, M. L. Apel, and C. L. Brierley (ed.), Biohydrometallurgical technologies, vol. II. Fossil energy materials, bioremediation, microbial physiology. Proceedings of an International Biohydrometallurgy Symposium, Jackson Hole, Wyo. The Minerals, Metals, and Materials Society, Warrendale, $\mathrm{Pa}$.

12. Feig, S. 1973. Effects of supplementary aeration on the growth of Thiobacillus thiooxidans in shaken cultures. Can J. Microbiol. 19:306-307.

13. Felsenstein, J. 1981. Evolutionary trees for DNA sequences: a maximum likelihood approach. J. Mol. Evol. 17:368-376.

14. Felsenstein, J. 1985. Confidence limits on phylogenies: an approach using the bootstrap. Evolution 39:783-791.

15. Goebel, B. M., and E. Stackebrandt. 1994. Cultural and phylogenetic analysis of mixed microbial populations found in natural and commercial bioleaching environments. Appl. Environ. Microbiol. 60:1614-1621.

16. Golovacheva, R. S., and G. I. Karavaiko. 1978. A new genus of thermophilic spore-forming bacteria, Sulfobacillus. Microbiology 47:658-665.

17. Guay, R., and M. Silver. 1975. Thiobacillus acidophilus sp. nov.: isolation and some physiological characteristics. Can. J. Microbiol. 21:281-288.

18. Harrison, A. P., Jr. 1981. Acidiphilium cryptum gen. nov., sp. nov., heterotrophic bacterium from acidic mineral environments. Int. J. Syst. Bacteriol. 31:327-332.

19. Karavaiko, G. I., R. S. Golovacheva, T. A. Pivovarova, I. A. Tzaplina, and N. S. Vartanjan. 1988. Thermophilic bacteria of the genus Sulfobacillus. p. 29-41. In: BioHydroMetallurgy Proceeding of the International Symposium, Warwich 1987, Technology Letters, Antony Rowe Ltd, Chippenham, Wiltshire, United Kingdom.

20. Kimura, M. 1980. A simple method for estimating evolutionary rate of base substitutions throught comparative studies of nucleotide sequences. J. Mol. Evol. 16:111-120.

21. Kumar, S., K. Tamura, and M. Nei. 1993. MEGA: molecular evolutionary genetics analysis version 1.0. The Pennsylvania State University, University Park.

22. Lane, D. J., A. P. Harrison, Jr., D. Stahl, B. Pace, S. J. Giovannoni, G. J. Olsen, and N. R. Pace. 1992. Evolutionary relationship among sulfur and iron-oxidizing eubacteria. J. Bacteriol. 174:269-279.

23. Lowry, O. H., N. J. Rosenbrough, A. L. Farr, and R. J. Randall. 1951. Protein measurement with Folin phenol reagent. J. Biol. Chem. 193:265-275.

24. Maidak, B. L., N. Larsen, G. J. Olsen, M. J. McCaughey, R. Overbeek, T. J. Macke, K. Fogel, J. Blandy, and C. R. Woese. 1994. The ribosomal database project. Nucleic Acids Res. 22:3485-3487.

25. Marmur, J. 1961. A procedure for the isolation of deoxyribonucleic acid from microorganisms. J. Mol. Biol. 3:208-218.

26. Marmur, J., and P. Doty. 1961. Thermal renaturation of deoxyribonucleic acids. J. Mol. Biol. 3:585-594.

27. Marsh, R. M., and P. R. Norris. 1983. The isolation of some thermophilic, autotrophic iron- and sulphur-oxidizing bacteria. FEMS Microbiol. Lett. 17:311-315.

28. Murray, R. G. E., R. S. Doetsch, and C. F. Robinow. 1994. Determinative and cytological light microscopy. p. 21-41. In P. Gerhardt, R. G. E. Murray, W. A. Wood, and N. R. Krieg (ed.), Methods for general molecular bacteriology. American Society for Microbiology, Washington, D.C.

29. Poralla, K. (Universität Tübingen). 1996. Personal communication.

30. Saitou, N., and M. Nei. 1987. The neighbor-joining method: a new method for reconstructing phylogenetic trees. Mol. Biol. Evol. 4:406-425.

31. Segerer, A., A. Neuner, J. K. Kristjansson, and K. O. Stetter. 1986. Acidianus infernus gen. nov., sp. nov., and Acidianus brierleyi comb. nov.: facultatively aerobic, extremely acidophilic thermophilic sulfur-metabolizing archaebacteria. Int. J. Syst. Bacteriol. 36:559-564.

32. Silverman, M. P., and D. G. Lundgren. 1959. Studies of the chemoautotrophic iron bacterium Ferrobacillus ferrooxidans. I. An improved medium and a harvesting procedure for securing high cell yields. J. Bacteriol. 77:642-647.

33. Stackebrandt, E., and B. M. Goebel. 1994. Taxonomic note: a place for DNA-DNA reassociation and 16S rRNA sequence analysis in the present species definition in bacteriology. Int. J. Syst. Bacteriol. 44:846-849.

34. Swofford, D. L. 1993. PAUP-phylogenetic analysis using parsimony, version 3.1. Illinois Natural History Survey, Champlain, Ill.

35. Tourova, D. P., A. B. Poltoraus, I. A. Lebedeva, I. A. Tsaplina, D. I. Bogdova, and G. I. Karavaiko. 1994. 16S ribosomal RNA (rDNA) sequence analysis and phylogenetic position of Sulfobacillus thermosulfidooxidans. Syst. Appl. Microbiol. 17:509-512.

36. Tsaplina, I. A., G. A. Osipov, T. I. Bogdanova, T. P. Nedorezova, and G. I. Karavaiko. 1994. Fatty-acid composition of lipids in thermoacidophilic bacteria of the genus Sulfobacillus. Microbiology 63:459-464. 